\title{
Pelatihan Pengolahan Vertical Garden dan Penggunaan Alat Kesehatan Masyarakat Di Dusun Samirono, Caturtunggal, Depok, Sleman, Yogyakarta
}

\section{Vertical Garden Processing Training and Use of Community Health Devices In Hamlet Samirono, Caturtunggal, Depok, Sleman, Yogyakarta}

\author{
Siti Nurhalizah*, Endah, Pradini Syarifah Ramadhani, Andi Mustofa \\ Jurusan Pendidikan Biologi, FMIPA, Universitas Negeri Yogyakarta,
}

Email: sitinurhalizah.2017@student.uny.ac.id

\begin{abstract}
Abstrak
Padatnya perumahan penduduk dan kurangnya kepedulian masyarakat terhadap kesehatan jasmani, mengakibatkan sedikitnya masyarakat yang memiliki kebun diperkarangan mereka dan sebagian acuh terhadap kondisi kesehatan fisiknya, mengakibatkan mudahnya terserang penyakit.Tujuan dari layanan ini adalah (1) untuk meningkatkan konsep pengetahuan masyarakat tentang cara mengelola limbah dalam botol bekas dengan metode taman vertikal (2) untuk meningkatkan pengetahuan masyarakat tentang cara menggunakan perangkat medis. Ada aktivitas servise yang dilakukan dalam satu bulan dengan pertemuan dalam beberapa minggu. Dengan tujuan kegiatan tersebut adalah masyarakat dan ibu-ibu pengurus PKK desa Samirono. Ada aktivitas layanan yang dilakukan melalui bimbingan.Hasil layanan dijelaskan secara deskriptif kualitatif. Hasil layanan ini menunjukkan bahwa layanan berhasil.
\end{abstract}

Kata kunci: pelatihan pengelolahan sampah, vertical garden, penggunaan alat-alat kesehatan

\section{Abstract}

There is full citizen house resulted in the small number of people here garden. In their fields while lack of concerning about physical healt, result in easily attacted by disease. The purpose of this service are (1) To improve the concept of community knowledge about how to manage waste in the used bottles with the vertical garden method (2) To increase public knowledge about how to use medical devices. There is servise activity carryed out in one mounth with on meeting in weeks. with the aim of the activity were the community and mothers of the PKK administrators of vilage Samirono. There is service activity carried out through guidance. The result of the service are described by qualitatively descriptiviely. The results of this service indicated that service was success.

Key words: waste management training, vertical garden, use of medical devices

\section{PENDAHULUAN}

Perkotaan didefinisikan sebagai suatu kawasan permukiman bukan pedesaan namun memiliki nuansa kekotaan dengan satu kesatuan jaringan dalam penyediaan sarana maupun prasarana sehingga memiliki simpul kegiatan yang saling terkait satu sama lain (Suwarno, 2001).

Kota akan selalu tumbuh dan berkembang sejalan dengan perkembangan kehidupan sosial- budaya, ekonomi dan politik yang melatar belakanginya.
Perkembangan kota merupakan hasil karya dari konstruksi pemikiran manusia baik dalam tataran adaptasi terhadap lingkungan maupun adjustment (Tallo, Pratiwi2, \& Astutik, 2014). Perkembangan kota selalu berbanding lurus dengan laju pertumbuhan penduduk serta kegiatannya. Dimana semakin meningkatnya penduduk atau warga di sebuah kota maka kebutuhan akan lahan pun turut meningkat. Pemanfaatan seperti gedung perkantoran, pusat perbelanjaan, hotel dan perumahan termasuk diantaranya. 
Pertumbuhan penduduk yang sangat pesat serta bertambahnya tuntutan kebutuhan masyarakat akan lahan, seringkali mengakibatkan benturan kepentingan atas penggunaan lahan dengan rencana peruntukannya. Sedangkan lahan itu sendiri bersifat terbatas dan tidak bisa ditambah kecuali dengan kegiatan reklamasi (Eko \& Rahayu, 2012).

Seperti misalnya didaerah Samirono RT 11, Kabupaten Sleman merupakan daerah yang cukup dekat dengan salah satu kampus besar di Daerah Istimewa Yogyakarta serta dikelilingi oleh industriindustri yang cukup besar. Sehingga peluang bisnis yang tersedia pun cukup menjajikan. Hal ini yang kemudian menjadikan Samirono memiliki lahan bebas atau hijau yang sangat minim. Menurut (Husodo, 2013) berkurangnya luasan lahan hijau dapat menyebabkan resapan air berkurang, lingkungan menjadi gersang dan panas, serta hilangnya keanekaragaman flora dan fauna.

Dan penghijauan merupakan salah satu kegiatan penting yang harus dilaksanakan secara konseptual dalam menangani krisis lingkungan. Dalam konteks keruangan, penghijauan sangat dibutuhkan terutama untuk kota-kota yang sedang berkembang dan mengalami alih fungsi ruang untuk kawasan terbangun (Rubiantoro \& Haryanto, 2013). Akan tetapi kendala yang dihadapi masyarakat perkotaan salah satunya sempitnya lahan atau minim lahan perkarangan yang akan digunakan sebagai penghijauan di masyarakat atau rumah (Asropah, Septiana, \& Indrariani, 2016).

Pengaturan tentang ruang terbuka hijau ini pada dasarnya telah diberikan melalui peraturan kota. Pemerintah Kota Yogyakarta telah mengeluarkan regulasi dalam bentuk peraturan walikota yakni Peraturan Walikota Yogyakarta Nomor 5 Tahun 2007 tentang Peengelolaan Ruang Terbuka Hijau dan Peraturan Walikota Yogyakarta Nomor 6 Tahun 2010 tentang Penyediaan Ruang Terbuka Hijau Privat. Hal ini menunjukkan komitmen yang tinggi antara pemerintah dan masyarakat akan pentingnya area hijau dilingkungan. Namun di Samirono hal ini terkendala oleh keterbatasan lahan yang tersedia karena banyaknya pembangunan proyek yang dilakukan dan mengurangi ketersediaan ruang terbuka hijau.

Permasalahan yang juga menaungi perkotaan ialah penumpukan sampah plastik yang tiada hentinya. Meningkatnya penggunaan plastik adalah konsekuensi dari perkembangan teknologi, industri dan populasi (Sari, Prasetyo, \& Kurniawan, 2017).

Volume timbunan sampah yang terus meningkat memerlukan pengelolaan. Pengelolaan sampah yang tidak menggunakan metode dan teknik pengelolaan sampah yang ramah lingkungan selain akan dapat menimbulkan dampak negatif terhadap kesehatan juga akan sangat mengganggu kelestarian fungsi lingkungan baik lingkungam pemukiman, hutan, persawahan, sungai dan lautan (Budiono, 2017). Sehingga diperlukan pengelolaan sampah plastik yang tepat dan tidak merugikan lingkungan.

Selain permasalahan lingkungan, kesehatan pun kini menjadi isu penting diberbagai wilayah di Indonesia. Terutama kesehatan pada lansia atau lanjut usia. Besarnya populasi lanjut usia serta pertumbuhan yang sangat cepat menimbulkan berbagai permasalahan, sehingga lanjut usia perlu mendapatkan perhatian yang serius dari semua sektor untuk upaya peningkatan kesejahteraan (Vicktoria, Kandou, \& Massie, 2015). Untuk itu kini telah gencar dilaksanakan posyandu lansia.

Indonesia sebagai salah satu negara berkembang masih mempunyai berbagai macam masalah kesehatan, salah satunya adalah hipertensi. Kejadian prevalensi hipertensi di Indonesia mencapai 31,7\% dari total penduduk dewasa, dengan jumlah mencapai $6,8 \%$ dari proporsi penyebab kematian pada semua umur di Indonesia (Amalia, 2013).

Pengukuran tekanan darah merupakan salah satu kegiatan posyandu lansia yang 
dilakukan oleh para kader diwilayahnya masing-masing. Menurut (Profita, 2018) kader memiliki peran besar terhadap lancarnya proses pelayanan kesehatan salah satunya kegiatan posyandu.

Akan tetapi, di daerah Samirono, Kabupaten Sleman kader kesehatan lansia sangat minim atau kurang, terutama dalam pengukuran tekanan darah. Hal ini yang menjadi kendala dalam setiap kegiatan posyandu lansia didaerah tersebut. Sehingga sangat diperlukan adanya kader-kader penerus atau tambahan dalam hal pengukuran tekanan darah dan cek kesehatan lainnya. Karena keberlangsungan posyandu tidak dapat dipisahkan dari peran kader dalam pelaksanaan posyandu, oleh karena itu pengetahuan dan ketrampilan kader harus selalu ditingkatkan (Triyanti, Widagdo, \& M, 2017). Keberhasilan posyandu ditentukan kinerja kader posyandu, karena kader adalah penggerak posyandu dan hidup matinya posyandu tergantung aktif tidaknya kader (Sary \& Puspasari, 2018).

Adanya keberadaan sampah, khususnya sampah rumah tangga seperti botol bekas yang sangat memprihatinkan , perlu disikapi dengan pengelolahan sampah yang tepat. Salah satunya ialah vertical garden. Mengingat kondisi lahan perkotaan yang semakin berkurang. Selain itu, masyarakat juga kekurangan konsep mengenai cara menggunakan alat-alat kesehatan untuk para lansia dengan begitu perlunya bimbingan khusus untuk penggunaan alat-alat tersebut. Dengan tujuan untuk membentuk kader-kader penerus bagi posyandu lansia. Sasaran kegiatan ilmu lingkungan adalah ibu-ibu pengurus PKK dan masyarakat di daerah Samirono. Metode kegiatan ini menggunakan metode pengabdian.

\section{SOLUSI/TEKNOLOGI}

Solusi yang kami sarankan ialah pembuatan vertical garden dengan memanfaatkan sampah botol plastic bekas dan pembinaan penggunaan alat-alat cek kesehatan. Penanaman yang dilakukan pada struktur vertikal seperti tanggul atau dinding penahan (retaining wall). Pada umumnya vertical greenery dibangun untuk menahan lereng yang berfungsi untuk membantu meningkatkan kestabilan lereng. Fungsi lain dari penanaman cara ini adalah menjadikan dinding atau lereng lebih menarik dan dapat menciptakan habitat bagi satwa (Arifin dkk, 2008 dalam Muhammad \& Setiawan, 2002).

Blanc (Muhammad \& Setiawan, 2002), menyatakan bahwa vertical garden atau vertical greenery merupakan tanaman yang disusun secara vertikal dan dapat menciptakan iklim mikro yang spesifik di sekitarnya, karena tanaman berperan penting dalam keseimbangan lingkungan. Tanaman dapat menyediakan ruang yang sejuk dan kaya oksigen untuk manusia. Dalam arti lain vertical garden merupakan suatu gagasan memindahkan efek natural ke dalam sebuah lingkungan perkotaan.

Konsep vertical garden memberikan manfaat, antara lain: menambah keindahan alami lingkungan, menciptakan taman indah di lahan terbatas menahan panas dari luar mengurangi tingkat kebisingan suara,mengurangi polusi udara, menangkap partikel-partikel kotoran, mengurangi efek tampias hujan, meningkatkan suplai oksigen, dan menjadi salah satu ruang terbuka hijau untuk menjamin keberlangsungan keseimbangan ekosistem kota yang didalamnya meliputi keseimbangan sistem hidrologi, keseimbangan mikroklimat, dan sistem ekologis lain yang dapat meningkatkan ketersediaan udara bersih yang diperlukan masyarakat, ruang terbuka bagi aktivitas publik serta sekaligus dapat meningkatkan nilai estetika kota (Hakim,2004 dalam Dharmadiatmika, 2017).

Vertical greenery memberikan dampak positif bagi lingkungan sekitar terutama bagi perubahan lingkungan daerah perkotaan yang padat. Adanya vertical greenery dapat mengurangi dampak emisi, contohnya pada area parkir atau jalan raya di pusat kota. Vertical greenery dengan sejumlah massa daun tanaman yang ada, 
dapat menyerap karbondioksida (CO2) dan partikel logam berat. Manfaat yang diperoleh oleh vertical greenery tergantung pada faktor desain yang meliputi luas daun, kerapatan daun, kondisi lokasi dan skala proyek. adapun teknologi yang digunakan untuk kegiatan ini baik, metode vertikel maupun penggunaan alat-alat kesehatan untuk para lansia.

Cara pertama untuk teknologi metode vertikal yang diterapkan di dusun samirono untuk memperhijau lingkungan di desa tersebut, memiliki dampak positif untuk kesehatan dan botol yang tidak digunakan lagi bisa di daur kembali dan dijadikan metode vertikal untuk tanaman jenis sayursayuran seperti bayam dan kangkung. secara umum teknologi dengan metode vertikal menggunakan botol, bisa mengurangi keberadan sampah yang berlebihan dan botol tersebut bisa bermanfaat kembali. cara kedua untuk teknologi Pembinaan dan pelatihan penggunaan alat-alat kesehatan dilakukan dengan cara memberikan pemahaman konsep, memberikan contoh, dan praktik kepada ibu-ibu PKK dusun Samirono di selang kegiatan pengecekan kesehatan lansia pada tanggal 15 hingga 20 di setiap bulannya.

\section{HASIL DAN DISKUSI}

Hasil Pengamatan

\begin{tabular}{lll}
\hline Komponen Lingkungan & Sifat/ Parameter & Ukuran \\
\hline $\begin{array}{lll}\text { Komponen Abiotik } \\
\text { (Unsur A) }\end{array}$ & Suhu Udara & $31^{\circ} \mathrm{C}$ \\
& Kelembaban Udara & $60 \%$ \\
& Intensitas Cahaya & $1012,4 \mathrm{Hpa}$ \\
& Kecepatan Angin & $8.3 \mathrm{~km} / \mathrm{jam}$ \\
\hline
\end{tabular}

\begin{tabular}{|c|c|c|}
\hline $\begin{array}{c}\text { Komponen Biotik } \\
\text { (Unsur B) }\end{array}$ & $\begin{array}{c}\text { Jenis - Jenis } \\
\text { yang Digunakan }\end{array}$ & Keterangan \\
\hline Bibit sayuran hijau & $\begin{array}{l}\text { Sawi,Bayam, } \\
\text { Kangkung }\end{array}$ & Bibit \\
\hline Kompos & & Media tanam \\
\hline Sumber daya manusia & $\begin{array}{l}\text { - Masyarakat RT } 11 \\
\text { - Ibu-ibu pengurus } \\
\text { PKK dusun } \\
\text { Samirono }\end{array}$ & $\begin{array}{l}\text { - Ketua RT } 11 \text { ahli } \\
\text { dalam bidang } \\
\text { pertanian } \\
\text { - Kader kesehatan } \\
\text { masyarakat }\end{array}$ \\
\hline
\end{tabular}




\begin{tabular}{llcll}
\hline Tanaman & Indikator & Subur & $\begin{array}{l}\text { Kurang } \\
\text { subur }\end{array}$ & $\begin{array}{l}\text { Tidak Subur/ } \\
\text { mati }\end{array}$ \\
\hline Bayam, sawi \\
dan kangkung & Nutrisi tanaman & $\checkmark$ & & \\
& tercukupi & & \\
& Tinggi tanaman & $\checkmark$ & \\
& Warna daun & $\checkmark$ & \\
& (layu/mati) & & \\
& Tanah memiliki & $\checkmark$ & \\
& unsur hara & & \\
& Tingkat & $\checkmark$ & \\
& keasaman tanah \\
& & & \\
& & & \\
& & & \\
\end{tabular}

\begin{tabular}{llclc}
\hline Aspek & Indikator & Berhasil & $\begin{array}{l}\text { Kurang } \\
\text { Berhasil }\end{array}$ & $\begin{array}{l}\text { Tidak } \\
\text { Berhasil }\end{array}$ \\
\hline $\begin{array}{l}\text { Audience vertical } \\
\text { garden }\end{array}$ & $\begin{array}{l}\text { Kehadiran peserta di } \\
\text { kegiatan }\end{array}$ & $\checkmark$ & & \\
& $\begin{array}{l}\text { Antusias Peserta } \\
\text { besar }\end{array}$ & $\checkmark$ & & \\
& $\begin{array}{l}\text { Keaktifan peserta } \\
\text { Audience cek }\end{array}$ & & $\checkmark$ & \\
kesehatan & $\begin{array}{l}\text { Antusias peserta } \\
\text { besar }\end{array}$ & $\checkmark$ & \\
\hline
\end{tabular}

\section{HASIL DAN DISKUSI}

Berdasarkan pembicaraan yang telah dilakukan dengan kepala dusun Samirono, beliau menyatakan bahwa dengan keadaan lingkungan yang saat ini, masyarakat Samirono merasa kekurangan akan adanya ruang terbuka hijau (RTH) dan kekurangan kader kesehatan lansia.

Pada kegiatan pengabdian bersama masyarakat dusun Samirono RT 11 yang bekerja sama dengan Ketua RT 11 yang mana beliau dan istrinya ahli dalam bidang pertanian dilakukan pembuatan vertical garden dengan memanfaatkan sampah botol plastic bekas yang berasal dari rumah warga local dan para mahasiswa yang bertempat tinggal di Samirono. Penggunaan botol bekas ini dilakukan sebagai langkah untuk mengurangi banyaknya sampah botol plastik yang terbuang dan mencemari lingkungan.
Botol-botol bekas ini dikumpulkan dan dibersihkan kemudian dipotong secara horizontal dengan sepertiga bagian terbuka dan lubang pada bagian kanan an kiri

sebagai tempat pemasangan tali pengait. Dengan tali yang panjang vertical garden botol bekas ini dapat pula disusun menjadi 2 atau 3 botol. Botol yang telah di potong akan diisi dengan tanah dan kompos kemudian bibit tanaman ditanam dan pot botol ini digantungkan di dinding/ pekarangan rumah warga. 


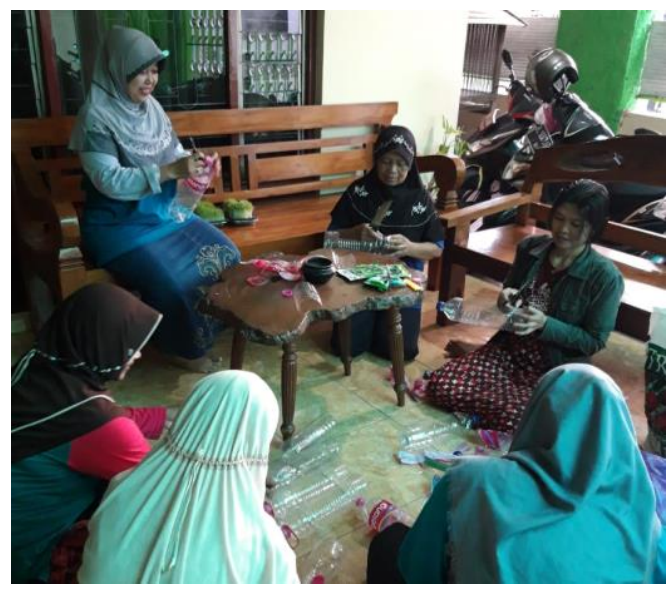

Gambar 1. Proses pembuatan vertical garden

Pada sebagian wilayah dusun Samirono telah menerapkan pembuatan vertical garden ini di dinding pembatas jalan dusun. Namun, berdasarkan pengamatan yang telah dilakukan vertical garden tersebut banyak yang tidak terawat dan mati. Hal ini dikarenakan letak vertical garden dibuat merupakan lokasi umum dan jarang warga yang mengurus. Oleh karena itu, kegiatan pengolahan vertical garden ini ditargetkan untuk diterapkan di rumah masing-masing warga agar dapat terawat dengan baik dan menjadi bagian dari program Ruang Terbuka Hijau Privat.

Tanaman yang digunakan untuk kegiatan ini berfokus pada tanaman pangan berupa sayuran. Sayuran yang digunakan ialah bibit sayuran Bayam, Kangkung dan Sawi. Sayuran hijau merupakan sumber nutrisi yang baik bagi tubuh manusia berupa protein nabati, zat besi, dan lain-lain. Hal ini ditujukan agar masyarakat menyadari pentingnya manfaat nutrisi yang terkandung dalam sayuran dan pemenuhan kebutuhan sayuran bagi kesehatan. Penanaman sayuran dengan metode vertical garden ini juga dapat mengurangi pengeluaran anggaran belanja ibu-ibu dusun Samirono RT 11 untuk membeli sayuran apabila dapat menanam sendiri dengan lebih praktis dan tidak memerlukan banyak lahan.

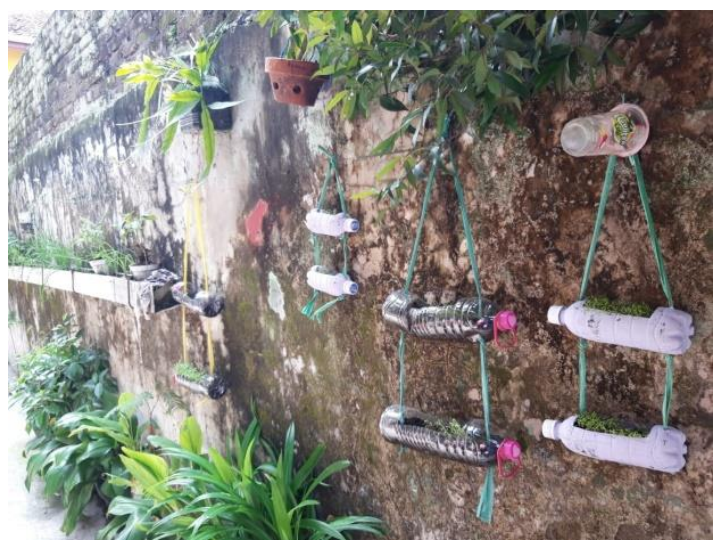

Gambar 2. Penerapan vertical garden

Pada kegiatan ini dilakukan monitoring setiap minggunya terhadap tanaman vertical garden yang dibuat. Sesuai table hasil pengamatan diatas sayuran yang ditanam dapat tumbuh dengan baik karena beberapa factor yang mendukung baik dari komponen biotik maupun abiotic. Dimana wilayah lingkungan Samirono memiliki data abiotic selama kegiatan yang berupa data iklim dengan rata-rata suhu sekitar $31^{\circ} \mathrm{C}$, kelembaban udara $60 \%$, intensitas cahaya 1012,4 Hpa, dan juga kecepatan angin 8,3 $\mathrm{km} / \mathrm{jam}$. Data abiotic ini menunjukkan bahwa lokasi tersebut cukup baik untuk pertumbuhan sayuran yang ditanam pada media vertical garden.

Kegiatan pelatihan penggunaan alat kesehatan di dusun Samirono dilakukan sebagai pemenuhan terhadap kebutuhan masyarakat Samirono akan kader kesehatan lansia yang masih kurang. Kader kesehatan lansia ini dilaksanakan oleh ibu-ibu PKK dusun Samirono yang dilakukan rutin 4 kali ke beberapa RT secara bergantian pada setiap bulan di tanggal 15 hingga tanggal 20 .

Kegiatan kader lansia di posyandu lansia berupa pengecekan berat badan, tinggi badan, cek tekanan darah, cek kadar gula darah, asam urat, dan kolestrol. Kegiatan ini dilakukan sebagai tindakan waspada kondisi kesehatan lansia didaerah Samirono, Kabupaten Sleman. Namun, kader kesehatan lansia sangat minim atau kurang dikarenakan para ibu-ibu merasa belum memahami penggunaan tensimeter alcohol terutama dalam mendengarkan 
hitungan detak jantung yang terdengan sebagai penentu tekanan sistole dan diastole serta ibu-ibu yang masih ragu dalam pengambilan sampel darah untuk cek kadar gula darah, kolestrol dan asam urat.
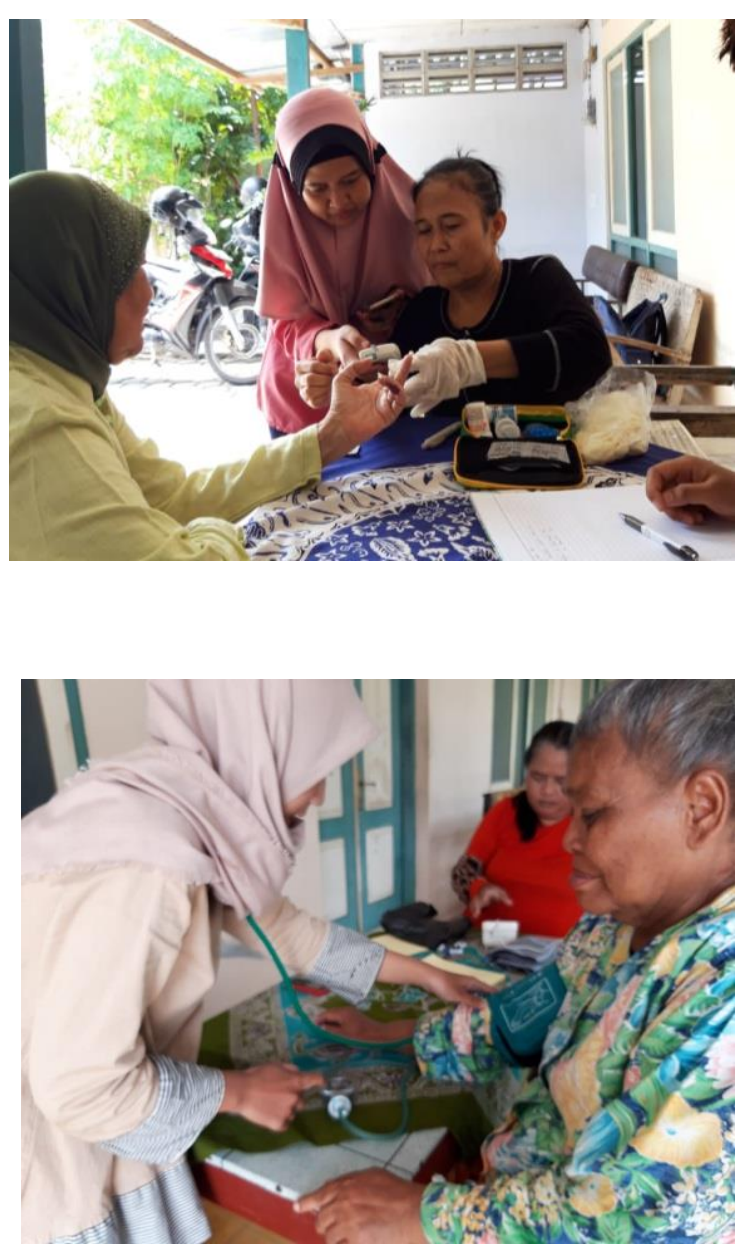

Gambar 3. Pelatihan pengecekan kadar gula darah, kolesterol dan asam urat

Pelatihan dilakukan dengan cara mengikuti kegiatan ibu-ibu PKK di posyandu lansia beberapa RT di dusun Samirono. Dalam pengecekan kesehatan diberikan beberapa contoh dan pemahaman tentang penggunaan tensimeter manual dan cara mendapatkan data ketukan detak jantung tepat. Dimana ketukan pertama yang terdengar dan ketukan terakhir menentukan systole dan diastole.

Tekanan sistolik adalah tekanan darah pada saat terjadi kontraksi otot jantung. Istilah ini secara khusus digunakan untuk merujuk pada tekanan arterial maksimum saat terjadi kontraksi pada lobus ventrikular kiri dari jantung. Rentang waktu terjadinya kontraksi disebut systole. Tekanan diastolik adalah tekanan darah pada saat jantung sedang berelaksasi atau beristirahat. Pada format penulisan angka tekanan darah, umumnya, tekanan sistolik merupakan angka pertama. Sebagai contoh, tekanan darah pada angka 120/80 menunjukkan tekanan sistolik pada nilai $120 \mathrm{mmHg}$ dan $80 \mathrm{mmHg}$ menunjukkan tekanan diastolic.

Kemudian untuk pengambilah darah pengecekan kadar gula darah, asam urat, dan kolestrol ibu-ibu PKK kesehatan diberikan pemahaman tentang cara pengambilan darah yang benar dan teknik pengecekan secara aseptic. Pemahaman teknik dan praktik dilakukan secara terbuka agar ibu-ibu PKK yang hadir dapat belajar dan mampu menjadi kader kesehatan di dusun Samirono. Gambar 4. Pelatihan penggunaan tensimeter Kegiatan pengabdian belum sepenuhnya berjalan dengan baik dikarenakan beberapa factor. Faktor pendukung kegiatan pengabdian ini ialah adanya antusiasme peserta pengabdian dan masyaratat yang ingin belajar mengelola sampah, membuat vertical garden, dan cara menggunakan alat-alat kesehatan sedangkan faktor penghambat kegiatan adalah keterbatasan waktu dalam pelaksanaan pengabdian, serta lokasi pengabdian yang belum mencakup keseluruhan dusun Samirono. Maka untuk kegiatan yang telah dilakukan diharapkan tetap dilaksanakan dengan baik dan untuk kegiatan selanjutnya diharapkan dapat lebih baik lagi dan mampu mencakup keseluruhan wilayah dusun Samirono.

\section{KESIMPULAN}

Pemanfaatan botol bekas untuk dijadikan vertical garden dan menggunakan sayuran hijau sebagai objek tanam merupakan model inovasi untuk pengembangan Ruang Terbuka Hijau Privat di Dusun Samirono dan juga sebagai media untuk pemenuhan nutrisi pangan yang bersumber dari sayuran guna menunjang 
kesehatan masyarakat. Kesehatan yang diharapkan dapat selalu sehat dengan dilakukannya pengecekan rutin setiap bulan terutama bagi lansia agar selalu waspada dan mampu menjaga pola hidup sehat dengan baik.

\section{UCAPAN TERIMA KASIH}

Ucapan terima kasih kami sampaikan kepada bapak-ibu ketua RT beserta masyarakat RT 11 Samirono dan ibu-ibu PKK dusun Samirono yang telah bersedia dan membantu dalam kegiatan pengabdian ini serta memaafkan segala bentuk kesalahan sikap maupun tutur kata yang dilakukan selama kegiatan berlangsung.

\section{PUSTAKA}

Amalia, icca s. (2013). Evaluasi Media Poster Hipertensi pada Pengunjung Puskesmas Talaga Kabupaten Majalengka. Jurnal Kesehatan Masyarakat, 9(02), 1-8.

Asropah, Septiana, I., \& Indrariani, ardiana e. (2016). Pemanfaatan Barang Bekas Botol Plastik dalam Pembuatan Vertical Garden. Jurnal Pengabdian Kepada Masyarakat, 07, 9-16.

Budiono. (2017). Pemanfaatan Limbah Botol Plastik menjadi Prakarya Boneka Pinguin sebagai Bentuk Implementasi dari Pendidikan Lingkungan Hidup, 2(2), 113-118.

Dharmadiatmika, I. M. A. (2017). Konsep Penataan Ruang Terbuka Hijau Publik di Kota Kecamatan Mengwi, Kabupaten Badung , Provinsi Bali, 3(2), 213-222.

Eko, T., \& Rahayu, S. (2012). Perubahan Penggunaan Lahan dan Kesesuaiannya terhadap RDTR di Wilayah Peri-Urban Studi Kasus: Kecamatan Mlati, 8(4), 330-340.

Husodo, B. S. (2013). Pengawasan Ruang Terbuka Hijau Sebagai Kawasan
Perumahan Berdasarkan Peraturan Daerah Kota Madiun Nomor 06 Tahun 2011 Tentang Rencana Tata Ruang Wilayah Kota Madiun 2010-2030. Jurnal Ilmiah, 1-18.

Laloan, Y. R. Y., Prijadi, R., \& Moniaga, I. L. (2016). Apartemen di Manado "“ Penerapan Konsep Vertical Garden ," 10-18.

Muhammad, J., \& Setiawan, P. hari. (2002). Taman Vertikal Susun ( Vertical Garden Stacking ) sebagai Solusi Degradasi Ruang Terbuka Hijau di Kota Yogyakarta.

Profita, A. C. (2018). Beberapa Faktor yang Berhubungan dengan Keaktifan Kader Posyandu di Desa Pengadegan Kabupaten Banyumas. Jurnal Administrasi Kesehatan Indonesia, 6(2), 68-74. https://doi.org/10.20473/jaki.v6i2.2018 .68-74

Rubiantoro, E. A., \& Haryanto, R. (2013). Bentuk Keterlibatan Masyarakat dalam Upaya Penghijauan pada Kawasan Hunian Padat di Kelurahan Serengan Kota Surakarta. Pembangunan Wilayah Dan Koya, 9(4), 416-428.

Sari, D. M. M., Prasetyo, Y., \& Kurniawan, A. (2017). Metode Konversi Sampah Plastik Berupa Botol Plastik Bekas Melalui Budidaya Toga Lingkungan, 3(2), 85-98. https://doi.org/10.21111/agrotech.

Sary, Y. N. E., \& Puspasari, D. (2018). Pengaruh Pendidikan Kesehatan terhadap Keaktifan Kader di Desa Taman Kecamatan Grujugan Kabupaten Bondowoso. Jurnal Ilmiah Kesehatan, 7(2), 29-33. https://doi.org/10.30994/sjik.v7i2.166

Suwarno. (2001). Kajian Terhadap Terjadinya Kawasan Tumbuh Cepat Wilayah Perkotaan Yogyakarta. Universitas Diponegoro Semarang.

Tallo, A. J., Pratiwi2, Y., \& Astutik, I. (2014). Identifikasi Pola Morfologi Kota ( Studi Kasus: Sebagian Kecamatan Klojen, Di Kota Malang ), 
25(3), 213-227.

Triyanti, M., Widagdo, L., \& M, S. B. (2017). Peningkatan Pengetahuan dan Ketrampilan Kader Pemantauan Tumbuh Kembang Balita di Posyandu dengan Metode BBM dan Mind Mapping (MM), 12(2), 265-277.
Vicktoria, V. M., Kandou, G. D., \& Massie, R. G. A. (2015). Pemanfaatan Posyandu Lansia di Wilayah Kerja Puskesmas Teling Atas Kota Manado, 479-490. 